\title{
Ralph Lansky, Grundliteratur Recht (Basic Literature on Law), Auswahlbibliographie zur Rechtswissenschaft im allgemeinen und zum Recht der Bundesrepublik Deutschland (Selective Bibliography on Law in General and on the Law of the Federal Republic of Germany), 2nd Edition, C.H. Beck'sche Verlagsbuchhandlung, München1978, XXVIII and 161 pp.; paperback DM 24.-.
}

Citation for published version (APA):

de Groot, G-R. (1979). Ralph Lansky, Grundliteratur Recht (Basic Literature on Law),

Auswahlbibliographie zur Rechtswissenschaft im allgemeinen und zum Recht der Bundesrepublik Deutschland (Selective Bibliography on Law in General and on the Law of the Federal Republic of Germany), 2nd Edition, C.H. Beck'sche Verlagsbuchhandlung, München1978, XXVIII and 161 pp.; paperback DM 24.-. Netherlands International Law Review, 26(3), 360-361.

https://doi.org/10.1017/S0165070X00018209

Document status and date:

Published: 01/01/1979

DOI:

10.1017/S0165070X00018209

Document Version:

Publisher's PDF, also known as Version of record

Please check the document version of this publication:

- A submitted manuscript is the version of the article upon submission and before peer-review. There can be important differences between the submitted version and the official published version of record.

People interested in the research are advised to contact the author for the final version of the publication, or visit the DOI to the publisher's website.

- The final author version and the galley proof are versions of the publication after peer review.

- The final published version features the final layout of the paper including the volume, issue and page numbers.

Link to publication

\footnotetext{
General rights

Copyright and moral rights for the publications made accessible in the public portal are retained by the authors and/or other copyright owners and it is a condition of accessing publications that users recognise and abide by the legal requirements associated with these rights.

- Users may download and print one copy of any publication from the public portal for the purpose of private study or research.

- You may not further distribute the material or use it for any profit-making activity or commercial gain

- You may freely distribute the URL identifying the publication in the public portal.

If the publication is distributed under the terms of Article $25 \mathrm{fa}$ of the Dutch Copyright Act, indicated by the "Taverne" license above, please follow below link for the End User Agreement:

www.umlib.nl/taverne-license
}

Take down policy

If you believe that this document breaches copyright please contact us at:

repository@maastrichtuniversity.nl

providing details and we will investigate your claim. 
RALPH LANSKY, Grundliteratur Recht (Basic Literature on Law), Auswahlbibliographie zur Rechtswissenschaft im allgemeinen und zum Recht der Bundesrepublik Deutschland (Selective Bibliography on Law in General and on the Law of the Federal Republic of Germany), 2nd Edition, C.H. Beck'sche Verlagsbuchhandlung, München 1978, XXVIII and 161 pp.; paperback DM 24.-.

The bibliography compiled by Lansky deserves special attention by reason of the original and useful plan. The preceding edition of this bibliography appeared in 1974 as No. 1 of the Arbeitshefte der Arbeitsgemeinschaft für juristisches Bibliotheksund Dokumentationswesen.

To begin with, the bibliography is arranged in a particularly convenient way. The table of contents is based on the "Systematik der Rechtswissenschaft in Grundzügen" published by Lansky in 1968 at Bouvier's (Bonn) and appears in four languages (German, English, French and Spanish). The alphabetical index, too, contains references in these four languages.

Lansky's objective is to present a selection from the legal literature, intended for lawyers, libraries, and the German and foreign bookselling trade. He prefers not to mention too many titles and therefore deliberately confines himself to the description of a legal reference library consisting of 771 works in 2641 volumes. For further literature he refers to some non-selective bibliographies (such as the Karlsruher Juristische Bibliografie). Lansky states that the cost of the library described by him is DM 177,000 . (The purchase prices are given with each of the different works mentioned). It is particularly convenient that by means of asterisks Lansky has also indicated which of the works mentioned by him are most important; the cost of the sub-selection thus made from the standard library is estimated at $\mathrm{DM} 17,000$.

Lansky's bibliography should prove especially useful for foreign legal libraries, but just as much for "ordinary" foreign lawyers who need to investigate matters of German law. In fact, it is often extremely difficult for an outsider to judge which of the available handbooks in another legal system are really very important and which are only of secondary importance. To a certain extent it is natural to assume that voluminous books will be more important than slender works. But in practice one soon finds that the large size of a book is no guarantee of excellence at all: it often occurs that a voluminous book is hardly used by native lawyers, who may prefer handier works. With the aid of Lansky's bibliography a foreign lawyer can now easily ascertain which works are essential for him to consult on a question of German law with which he is concerned. In particular he must not omit to consult the books marked with an asterisk.

Foreign legal libraries which seek to maintain a German law collection will in my opinion have to purchase at least the books marked with an asterisk. In accordance with the interest of the users of the library the purchase of other books mentioned in the bibliography may also be considered. It is not until then that the purchase of "any other" literature should be undertaken. 
The present bibliography is an important contribution towards making German law accessible to foreign lawyers. Every country should compile such a bibliography, as part of its general obligation to make its law accessible to foreigners (I here follow D.C. Fokkema in his address "Begrensde gerechtigheid" (Justice subjected to Boundaries), Leiden 1963). Of course there are already the (very) concise bibliographies in the National Reports of the International Encyclopedia of Comparative Law, while the bibliographies in the Introduction bibliographique $\dot{a}$ l'histoire du droit et a l'ethnologie juridique of Gilissen also contain very useful material for students of contemporary comparative law. But these bibliographies decidedly do not yet render a work such as that of Lansky superfluous.

One is driven to compare Lansky's bibliography with the comprehensive "Selective Bibliography of Dutch Law" compiled by M.J.A. Langlois van den Bergh, pp. 595-660 of the "Introduction to Dutch Law for Foreign Lawyers", Deventer (Kluwer) 1978 (edited by D.C. Fokkema, J.M.J. Chorus, E.H. Hondius, and E.Ch. Visser; prepared under the auspices of the Netherlands Comparative Law Association). That bibliography also provides an excellent assistance to foreign lawyers, but it is slightly less selective than Lansky's. Moreover, it would be advisable to include a sub-selection such as that made by Lansky in the next edition of the Dutch bibliography. Thus, on pp. 607 to 609 there is a long enumeration of Dutch legal journals ( 51 titles), but a foreign lawyer cannot infer from this list that the "WPNR" (Weekblad voor privaatrecht, notariaat en registratie) is decidedly more important than the "Gerechtsdeurwaarder". In one respect Van den Bergh's bibliography seems to me superior to Lansky's: Van den Bergh includes a very detailed list of literature in foreign languages on the various subjects. He is to be given special credit for this, the more so because this literature in foreign languages is often very difficult to find. These references considerably facilitate the study of Dutch law for foreigners. Perhaps Lansky might also add some references to literature in foreign languages in the next edition. This would further enhance the usefulness of his bibliography for foreigners. Of course, it has to be admitted that the mention of literature in foreign languages in a bibliography on Dutch law is more urgent than in a bibliography on German law, since the knowledge of German is certainly more common abroad than that of Dutch.

My overall opinion about the bibliography of Lansky results logically from the above: I consider it an exemplary work and I hope that many countries will proceed to compile similar selective bibliographies. The study of comparative law will benefit thereby.

Gerard-René de Groot

M.E. TARDU, Human Rights, The Intemational Petition System, Dobbs Ferry, NY, Oceana, 1979, Binder I, Looseleaf, \$75.- (two other Binders projected at $\$ 75 .-$ each)

In the Note "Human Rights in Foreign Policy", which the Dutch Government produced in August 1979, it is stated that the promotion of human rights forms a corner stone of Dutch foreign policy. The promotion is focused on (1) building up an international set of rules on human rights, and (2) ensuring that these rules are observed in practice.

Their observance could be achieved by, inter alia, encouraging the creation and functioning of international supervisory procedures. Elsewhere in the Note it is observed that a considerable number of such international supervisory procedures already exists. It has always been the policy of the Netherlands to give these proce- 